DOI 10.18551/rjoas.2019-02.36

\title{
THE MEDIATION EFFECT OF WORK STRESS ON WORKLOAD, WORK CONDITION, AND LOAN COLLECTION PERFORMANCE
}

\author{
Sulistiyono Adincha Ayuvisda ${ }^{*}$, Narsa I Made \\ Department of Accounting, Faculty of Economics and Business, University of Airlangga, \\ Surabaya, Indonesia \\ *E-mail: adinchaayuvisda@gmail.com
}

\begin{abstract}
This study aims to prove ability the mediation effect of work stress on workload, work condition, and loan collection performance. This is a descriptive quantitative with an explanatory approach type of study. Samples are collected from Bank Mandiri CCR Surabaya and consist of 121 people from a total of 157. Data analysis technique used was path analysis technique. Results indicate that hypothesis are accepted and can mediate. This means that high workload caused increased work stress and impacted on loan collection performance decrease. Meanwhile good work environment condition caused decreased work stress and impacted on increasing loan collection performance.
\end{abstract}

\section{KEY WORDS}

Work stress, workload, work condition, loan collection, performance.

Bank is financial business institution having duty to collect and distribute funds into society by providing financial-related services and support society in improving living standard. Many societies borrow bank fund from KPR, collateral free loan and credit card. Credit allocation to consumer might involve risk including troubled credit, no obligation settlement according to agreement either in terms of amount and time. In terms of banking NPL ratio or troubled credit is credit risk measure serves as bank health level. If bank could suppress Non Performing Loan ratio below 5\% then it shall provide higher profit potential as bank could reduce receivable reserve fund or write off. Lower receivable reserve impact on higher bank profit and create better banking performance. The high NPL inseparable from loan collection performance that has not been optimal, which resulted in the company must be able to improve the performance of its employees.

Employee performance is work result or output, either in terms of quantity and quality that employee attain in completing their work with full responsibility (Mangkunegara, 2014). Employee role in company are crucial matter and required to develop. High employee performance shall lead to impact from company and employee themselves. For employee having excellent performance could provide reward for them amongst them increased salary, opportunity to promotion into higher level and making such employee more expert and experienced on their field. Low performance represents that such employee actually incompetent for their field, causing such employee hard to promote into higher level, and might cause such employee to resign or called employment termination. According to Griffin, Hogan et al. (2010), employment termination is dangerous negative response for employee and organization. Performance could be affected by several factors amongst them workload and Work condition (Adityawarman, Sanim et al, 2016; Putra, 2013).

The higher consumer have receivable will increase the load of the collection division employee who will have an impact on the high goal setting, limited working completion time and less supporting environment. Almost entire employee feel stressed with such issues that it could lead into stress due to workload and inability to complete work maximally could affect performance and company achievement as well. Research carried out by Carayon and Gurses (2005) stated that high workload could increase bad communication, collaboration failure, work dissatisfaction, reduced employee performance and employee resignation from company. It is similar with Astianto (2015) research mentioning that workload influence toward employee performance. It suggests that workload have positive and negative 
meaning for employee. Employee perceiving duty as challenge to complete though it is a hard assignment would remain comfortable with their work. Meanwhile for employee perceiving duty as hard assignment and burden then such employee would gradually suffer from exhaustion either physically and mentally that could lower performance.

It is also supported by research result of Shah, Jaffariet al. (2011) stating that workload positively influence toward performance in which high workload is extremely crucial assessment for supervisor to conduct, as it impacts on performance and bonus allocated for company. This research result different with research conducted by Murali, Basitet al. (2017). Such result found empirical evidence that workload do not have significant influence toward employee performance. Good work environment condition would grow employee comfort at work. Comfort feeling on work space could reduce boring situation at work. Good condition shall impact on employee performance improvement. In contrary, work space discomfort could lead into reduced employee performance. Research conducted by Kahya (2007) and Ali (2013) demonstrated that work environment influence toward performance which means the better work environment the better employee performance. This research result was in contrary with research conducted by Arianto (2013) stating that work environment do not influence toward performance.

Research result inconsistency in connection with workload and Work condition influences toward performance inspired researcher to enter a variable to bridge such inconsistency. Variable made as mediation in this research was work stress. In performing duty employee demanded to remain professional and deliver quality collection toward delinquent consumer. In addition to workload, other factor influencing work stress is work environment condition. Work condition is one factor encouraging employee to work optimally. Poor Work condition shall cause employee easily ill, difficult to think and increasing stress. This research is supported by Andrew and Kishokumar (2014) that provided empirical evidence that work environment and workload have influence on bank employee work stress.

Excessive stress would have adverse impact on employee amongst them inability to think clearly, finding it hard to make correct decision and the most concerned impact would be reduced performance. Therefore work stress control within company is crucial that stress could be maintained in correct level and increase employee performance. Workplace stress at critical level could cause physical effect that harm employee performance, their physical health, and also impact on organization as well (Giorgi, Arcangeliet al., 2017). This research was supported by Ahmed and Rezan by showing that high work stress could lower performance.

Subject in this research were PT. Bank Mandiri CCR Surabaya staff. Researcher considered PT. Bank Mandiri CCR Surabaya staff as research subject as it is the solely PT Bank Mandiri collection office in East Java, in terms of Home Loan (KPR), Collateral Free Loan (KTA), Credit Card (KK) and NPL which also called as non performing loan for 2017 financial statement that was categorized high (3.45\%) compared to Bank BNI with NPL of 2.3\%, BRI with $2.1 \% \mathrm{NPL}$ and Bank BRI with $2.66 \% \mathrm{NPL}$.

\section{LITERATURE REVIEW}

Role Stress or also called pressure at work refers to company employee role in facing situation that represents three forms, role ambiguity, role conflict and pressure size at work (role overload) (Wolfe \& Snoek, 1962). It could be concluded that role stress is situation where employee experiences emotional tension that would affect thinking process that duty being performed would be perceived hard and result in less maximal result.

Work size is work measure certain organizational position/unit should shoulder and multiplication between work volume and time norm according to Minister of Domestic Affair Regulation Number 12 year 2008. It could be interpreted that workload is a number of process or activity an employee must complete in certain period of time. When such employee able to complete such work and could adapt against duty provided, than it shall not be an workload and vice versa. 
Work condition or frequently referred to as work environment condition is any work physical, psychological aspect and work regulation that could affect work satisfaction and productivity attainment (Mangkunegara, 2010: 105). According to Sedarmayati (2011: 26), work environment is any condition at around workplace that would affect employee either directly or indirectly. Work environment is crucial part within company as it has direct effect toward employee in performing their work.

According to Robbins (2017: 429), stress is dynamic condition where individual faced into opportunity, obstacle, and desire, and the obtained result is crucial but could not be curtained. Company primary objective could not be separated from each employee role as company drive. Company leader are appropriate to understand each employee condition. When employee experience issue that could obstruct company performance then leader are expected to reduce and solve such issue, especially concerning work stress that should be sustainably managed for not obstructing company performance operation.

Performance is individual employee performance in managerial activities such as planning, investigation, coordination, evaluation, supervision, staff arrangement, negotiation, and representative (Mahoney, 1963). Performance appraisal is key factor in to develop employee effectively and efficiently, due to better policy or program for human resources within company. Individual performance appraisal is crucial for company growth, as it could reveal actual condition concerning employee performance.

Workload is an individual extrinsic factor which is one source of the emergence of pressure, because excessive workload. This condition demands employee to provide more energy than usual to complete work in terms of target attainment that company desire, but it depends on each individual, which means such duties shall only be well completed or not, depend on how individual perform workload being performed. Workload discussed in this research originated from work duration and weight as well as quantity either externally or internally in terms of loan collection. Astianto (2015) highlighted that workload simultaneously have significant influence toward employee performance.

In addition to workload, company also need to focus on Work condition. Employee would generally perceive work satisfaction as they are supported by well or sufficient Work condition or work environment. In contrary worse Work condition or work environment causing reduced employee performance, such Work condition factor indirectly influence employee performance itself and output toward company. Work condition discussed in this research refers to work environment condition at office, either physical environment and inter-team member work relationship that supporting one and another. Khan et al. (2011) also demonstrated that safe, prosper and satisfying Work condition also contribute in improving employee motivation toward work.

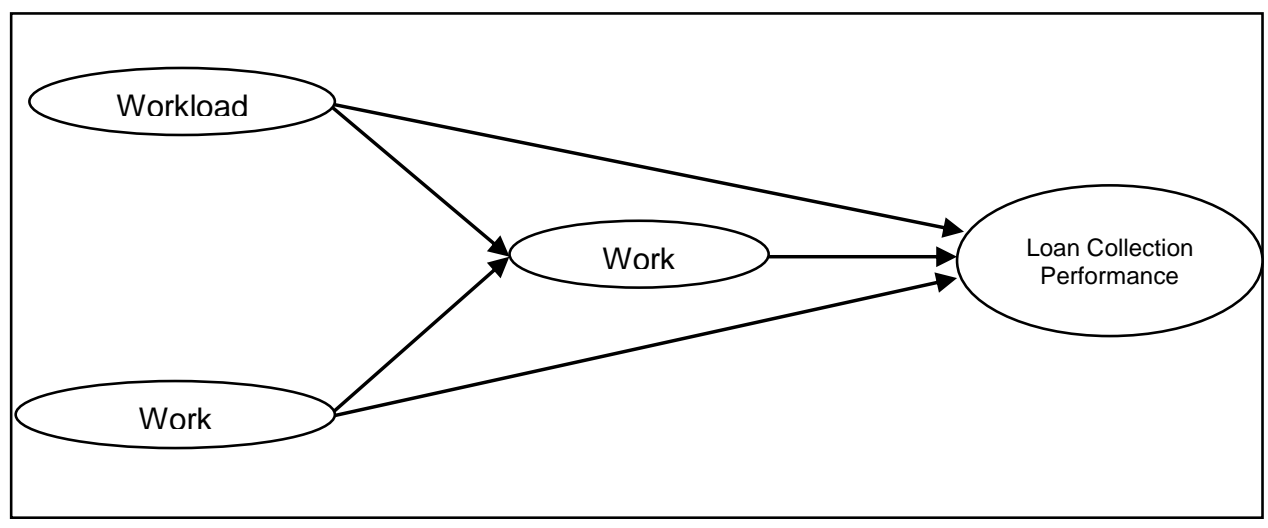

Figure 1 - Conceptual Framework

Workload and Work condition mediated by one mediating variable of work stress. Work stress could emerge when discrepancy occur between individual ability and work demands, and discrepancy between individual need with environmental fulfillment itself. Work stress must be handled properly because employee tendency would feel frustrated, emotional and 
uncomfortable at work, then it could trigger failure within organization because it can interfere with each other in doing the task. According to Sasono (2004) Work stress could be perceived as condition where individual experience duty or work that they could not accomplish or beyond their capability. Work stress lead into work implementation and employee performance.

Work stress Mediation toward Workload and Loan Collection Performance. Workload is process or activity employee must complete in company within certain period of time. Certain work that already becomes employee load must be completed to fulfill determined target. Not entire employee could perform their work well as they differ on capability level, it could cause stress and make employee not productive and lead into loan collection performance decrease. One of stress source according to Doelhadi (1995) is hard and urgent demanding situation. Research carried out by Saefullah (2017) provided empirical evidence that workload and work stress simultaneously have significant influence toward employee productivity.

$\mathrm{H} 1$ : Work stress mediates influence workload toward loan collection performance.

Work stress Mediation toward Work condition and Loan collection performance. Work environment condition is crucial matter for employee as it is directly related to their activity. Company must consider work environment in order to create excellent work environment and work condition that could provide comfort for employee to improve their performance. Work environment condition is workplace condition both physical or inter-employee relationship that could provide comfort and pleasure perception that could provide joy for employee to work. Sedarmayanti (2011: 26) defined work environment condition as any condition at around workplace that would affect employee either directly or indirectly. Supported with suitable work condition, it expected to improve employee performance with optimal result. Research conducted by Taiwo (2010) provided empirical evidence that conducive and better work environment are factors causing employee productivity improvement.

$\mathrm{H} 2$ : Work stress mediates influence Work condition toward loan collection performance.

\section{METHODS OF RESEARCH}

This research a descriptive quantitative with explanatory approach based on the available formulation. According to quantitative approach, this research also called as confirmatory analysis as it also focus on theoretical confirmation for the effectuation of certain research object, either for explanation as well as prediction (Sugiyono, 2017: 36).

There were three variables in this research namely independent variable, dependent variable and mediating variable. Independent variable in this research was workload and work condition. Loan collection performance served as dependent variable. Work stress served as mediating variable. Workload measure by indicators according to Hart and Stavelan (1988), among others: physical need, mental need, time need, work performance, effort, frustration level.

Work condition use indicators according to Sutanto (2015), among others: air temperature at workplace, layout at workplace, circulation at workplace, exposure level at workplace, inter-employee relationship at workplace, employee relationship with company leader at workplace.

Work stress use Indicators according to Lovibond (1995), among others: difficult to relax, raising nervous, easily angry/restless, disturbing/more reactive, impatient. Loan collection performance use indicators according to Mahoney et al. (1963), among others: planning, investigation, coordination, evaluation, supervision, staff selection, negotiation, representative.

Population in this research were entire collection staff of PT. Bank Mandiri, CCR Surabaya amounted to 157 employees per September $10^{\text {th }}$, 2018. Sample selection carried out using purposive sampling, sample determination technique through certain considerations (Sugiyono, 2017: 67). Total sample in this research were 121 respondents. 
Data collected through survey using questionnaire adopted from previous research. Upon data collected through questionnaire, editing performed to examine data quality. Followed by process using coding and tabulation, or grouping of sub variable being examined through scoring and rating to support submitted hypothesis. Path analysis technique used in this research as data analysis technique.

This research used data analysis technique using 5.0 PLS (Partial Least Square) version of WarpPLS software. It is a structural equation analysis or Structural Equation Model (SEM). In the first step, outer model (measurement model) test conducted to measure reflective (manifest) and formative (causal) indicators. Reflective or manifest indicator is based on loading factor. Loading factor $>0.70$ is highly recommended, but $0.50-0.60$ loading factor value still considered enough (Solimun, 2007: 15). Upon outer model test and measurement completed, inner model measurement carried out. Inner model measurement used to test relationship between variables in research using adjusted $R^{2}$ value (Sholihin, 2013: 72). Based on adjusted $R^{2}$, a model could be classified as strong $(\leq 0,70)$, moderate $(\leq$ $0.45)$ and weak $(\leq 0.25)$.

Causal steps were used to test mediating variable analysis. It was developed by Baron \& Kenny (1986). Product of Coefficient method were also used for this analysis that was developed by Sobel (1982). Sobel test carried out by testing indirect influence power of independent variable $(X)$ into dependent variable $(Y)$ through mediating variable $(Z)$. indirect influence of $X$ into $Y$ through $Z$ calculated by multiplying $X-Z$ path (a) with $Z-Y$ path (b) or ab. Therefor $a b$ coefficient $=\left(c-c^{\prime}\right)$ where $c$ is $X$ influence toward $Y$ without controlling $Y$ through $Z$, meanwhile $c^{\prime}$ is coefficient of $X$ influence toward $Y$ after controlling $Z$. standard error of $a$ and $b$ coefficient written with $\mathrm{Sa}$ and $\mathrm{Sb}$, that represents indirect effect standard error calculated through the following formula (Ghozali, 2013).

\section{RESULTS AND DISCUSSION}

Outer Model Measurement Estimation. Table 1 describes reflective value from indicator for each variable; workload variable, work condition, work stress and loan collection performance.

Table 1 - Final Iteration Outer Loading Factor Estimation Result

\begin{tabular}{|c|c|c|c|}
\hline Variable & Indicator & Outer Loading Value & Conclusion \\
\hline \multirow{4}{*}{ Workload } & WL2 & 0,801 & Significant \\
\hline & WL3 & 0,821 & Significant \\
\hline & WL5 & 0,712 & Significant \\
\hline & WL6 & 0,742 & Significant \\
\hline \multirow{7}{*}{ Work Condition } & WC7 & 0,532 & Significant \\
\hline & WC8 & 0,631 & Significant \\
\hline & WC10 & 0,813 & Significant \\
\hline & WC11 & 0,728 & Significant \\
\hline & WC12 & 0,865 & Significant \\
\hline & WC13 & 0,752 & Significant \\
\hline & WC14 & 0,807 & Significant \\
\hline \multirow{14}{*}{ Work Stress } & WS1 & 0,547 & Significant \\
\hline & WS2 & 0,620 & Significant \\
\hline & WS3 & 0,647 & Significant \\
\hline & WS4 & 0,632 & Significant \\
\hline & WS5 & 0,770 & Significant \\
\hline & WS6 & 0,879 & Significant \\
\hline & WS7 & 0,837 & Significant \\
\hline & WS8 & 0,877 & Significant \\
\hline & WS9 & 0,825 & Significant \\
\hline & WS10 & 0,828 & Significant \\
\hline & WS11 & 0,838 & Significant \\
\hline & WS12 & 0,709 & Significant \\
\hline & WS13 & 0,801 & Significant \\
\hline & WS14 & 0,721 & Significant \\
\hline \multirow{5}{*}{ Loan Collection Performance } & LCP4 & 0,763 & Significant \\
\hline & LCP5 & 0,577 & Significant \\
\hline & LCP7 & 0,775 & Significant \\
\hline & LCP8 & 0,797 & Significant \\
\hline & LCP10 & 0,851 & Significant \\
\hline
\end{tabular}


Based on result from Table 1, entire proxy had outer loading factor value greater 0.5 from new iteration result. Therefore, it could be concluded that entire proxy were feasible to be made as indicator that could reflect each related variables. From Table 1 result could also be concluded that second iteration was iteration to determine indicators used as reflective indicator for each variable.

Variables Validity and Reliability Test. Discriminant validity measurement result, AVE value must be greater than 0.30 or having $p$-value lower than significance level $(0.05)$. The following Table 2 presents discriminant value of this research.

Table 2 - Discriminant Validity Measurement Result

\begin{tabular}{|c|c|}
\hline Variable & Original Sample (O) \\
\hline Workload & 0,593 \\
\hline Work condition & 0,548 \\
\hline Work stress & 0,576 \\
\hline Loan collection performance & 0,575 \\
\hline
\end{tabular}

Source: Data processing, 2018.

According to Table 2, entire variable had discriminant validity value greater than 0.50 . Therefore it could be concluded that entire variables were valid.

Upon variables declared valid, reliability testing carried out using composite reliability technique. Reliability coefficient must be greater than 0.70 . Composite reliability measurement result is presented on Table 3.

Table 3 - Composite Reliability Measurement Result

\begin{tabular}{|c|c|}
\hline Variable & Original Sample (O) \\
\hline Workload & 0,853 \\
\hline Work condition & 0,893 \\
\hline Work stress & 0,949 \\
\hline Loan collection performance & 0,870 \\
\hline
\end{tabular}

Source: Data processing, 2018.

According to Table 3, entire variables had composite reliability value greater than 0.70 . According to this result, it could be concluded that entire variables were valid and could be relied to use in further analysis test.

Descriptive Analysis. Descriptive analysis is used to provide information about the variables used in the study, among others: workload, work condition, work stress and loan collection performance.

Table 4 - Descriptive Statistics

\begin{tabular}{|c|c|c|c|c|c|}
\hline & $\mathrm{N}$ & Minimum & Maximum & Mean & Std. Deviation \\
\hline Workload & 121 & 15 & 30 & 23.26 & 3.140 \\
\hline Work condition & 121 & 29 & 70 & 50.97 & 6.899 \\
\hline Work stress & 121 & 19 & 70 & 44.65 & 10.097 \\
\hline Loan collection performance & 121 & 24 & 50 & 39.16 & 4.710 \\
\hline Valid N (listwise) & 121 & & & & \\
\hline
\end{tabular}

Source: Data processing, 2018.

According to result on table 4 , the average value in the overall workload variable (6 item questions) is 3.88 with a high category, this indicates that PT Bank Mandiri CCR Surabaya has a relatively high workload. The average value in the overall work condition variable (14 item questions) is 3.64 with the high category. That is, the billing department employees owned by PT Bank Mandiri CCR Surabaya can be said that work conditions are in a high classification. This means that work facilities and infrastructure meet the standards.

The average overall work stress variable (14 item questions) is 3.19 with the disagree category. Showing that employees owned by PT Bank Mandiri CCR Surabaya can be said to 
have moderate stress levels. The average variable of overall loan collection performance (10 item questions) is 3.92 with the high category; this indicates that PT Bank Mandiri CCR Surabaya has a high loan collection performance.

Inner Model Test Result. Work stress mediating influence level on workload influence, Work condition toward loan collection performance, measured using inner model test. Inner model measurement serves to test work stress mediation on workload influence, Work condition toward loan collection performance within research $Q^{2}$ value was used. Inner model test result is presented on the following table 5 .

Table 5 - R-square Adjusted Value (Adjusted $R^{2}$ )

\begin{tabular}{|c|c|}
\hline Endogenous Variable & R-square Adjusted Value (Adjusted $\mathbf{R}^{2}$ ) \\
\hline Work stress & 0,123 \\
\hline Loan collection performance & 0,496 \\
\hline
\end{tabular}

Source: Data processing, 2018.

According to data presented on table 5 , the following predictive-relevance $\left(Q^{2}\right)$ calculation could be carried out.

$$
\mathrm{Q} 2=1-\left(1-\mathrm{R}^{2} \text { of work stress }\right)\left(1-\mathrm{R}^{2} \text { of loan collection performance }\right)=0,557912
$$

The above predictive-relevance $\left(Q^{2}\right)$ value calculation yielded $Q^{2}$ value of 0.557912 . it suggests that the constructed model could account work stress mediation on workload and Work condition influences toward loan collection performance as of $55.79 \%$, meanwhile the remaining 44.21 accounted by other variables outside this research.

Work stress Mediation Influence on Workload and Loan collection performance. Work stress mechanism used as mediating variable in workload influence toward loan collection performance calculated using Sobel test.

Table 6 - Sobel Test Result of Work stress as Workload Mediation Toward Loan collection performance

\begin{tabular}{|c|c|c|c|c|c|c|c|}
\hline Inter-Variable & $\begin{array}{l}\text { Path } \\
\text { Coefficients }\end{array}$ & $\begin{array}{l}\text { Standard } \\
\text { Error }\end{array}$ & $\begin{array}{l}\text { Standard } \\
\text { Error }\end{array}$ & $\begin{array}{c}\text { Standard Error } \\
\text { of Sobel Test }\end{array}$ & \multirow{2}{*}{$\begin{array}{c}\text { Sobel Test } \\
\text { Result (t-Sobel) }\end{array}$} & \multirow{2}{*}{$\begin{array}{c}\text { P- } \\
\text { value }\end{array}$} & \multirow[t]{2}{*}{ Conclusion } \\
\hline & & $(\mathrm{Sa})$ & $(\mathrm{Sb})$ & (Sab) & & & \\
\hline $\mathrm{WL} \rightarrow \mathrm{WS}$ & 0,194 & 0,014 & - & - & - & \multirow{3}{*}{0,0035} & \multirow{3}{*}{ Evidenced } \\
\hline WS $\rightarrow$ LCP & $-0,146$ & - & 0,049 & - & - & & \\
\hline $\mathrm{WL} \rightarrow \mathrm{WS} \rightarrow \mathrm{LCP}$ & $-0,0283$ & - & - & 0,0097 & $-2,913$ & & \\
\hline
\end{tabular}

Source: Data processing, 2018.

According to result on table 6 , it could be concluded that work stress could mediate workload influence toward loan collection performance. It was based on $p$ value $<0.01$, which means that work stress could mediate workload influence toward loan collection performance at $1 \%$ significance level.

Work stress Mediation Influence on Work condition and Loan collection performance. Work stress mechanism used as mediating variable in Work condition influence toward loan collection performance calculated using Sobel test.

Table 7 - Sobel Test Result of Work stress as Work condition Mediation toward Loan collection performance

\begin{tabular}{|c|c|c|c|c|c|c|c|}
\hline $\begin{array}{l}\text { Inter-Variable } \\
\text { Influence }\end{array}$ & $\begin{array}{c}\text { Path } \\
\text { Coefficients }\end{array}$ & $\begin{array}{c}\begin{array}{c}\text { Standard } \\
\text { Error }\end{array} \\
(\mathrm{Sa}) \\
\end{array}$ & $\begin{array}{c}\begin{array}{c}\text { Standard } \\
\text { Error }\end{array} \\
(\mathrm{Sb}) \\
\end{array}$ & $\begin{array}{c}\text { Standard Error } \\
\text { of Sobel Test } \\
\text { (Sab) }\end{array}$ & $\begin{array}{c}\text { Sobel Test } \\
\text { Result (t-Sobel) }\end{array}$ & $\begin{array}{c}\mathrm{P}- \\
\text { value }\end{array}$ & Conclusion \\
\hline $\mathrm{WC} \rightarrow \mathrm{WS}$ & $-0,376$ & $-0,001$ & - & - & - & \multirow{3}{*}{0,0029} & \multirow{3}{*}{ Evidenced } \\
\hline WS $\rightarrow$ LCP & $-0,146$ & - & 0,049 & - & & & \\
\hline $\mathrm{WC} \rightarrow \mathrm{WS} \rightarrow \mathrm{LCP}$ & 0,0548 & - & - & 0,0184 & 2,979 & & \\
\hline
\end{tabular}

Source: Data processing, 2018. 
According to result on table 7 , it could be concluded that work stress could mediate Work condition influence toward loan collection performance. It was based on $p$ value $<0.01$, which means that work stress could mediate workload influence toward loan collection performance at $1 \%$ significance level.

\section{DISCUSSION OF RESULTS}

Work stress as Workload Mediation toward Loan collection performance. This research result suggested that work stress could mediate workload influence toward loan collection performance. It means that high workload lead to increasing work stress and eventually impact on loan collection performance decrease. Performance decrease at banking institution especially on collection division could impact on high company NPL (Non Performing Loan. Increasing workload caused by enormous work to complete and strongly consume time to complete such work. High workload could drive employee stress work stress caused by several factors specifically employee difficulty to rest. Difficulty to rest and spend many energy to complete certain work. Increased employee work stress shall provide impact on loan collection performance decrease. This research result was in line with research carried out by Saefullah (2017) that provided evidence that workload and work stress have significant influence toward employee productivity.

Work stress as Work condition Mediation toward Loan collection performance. This research result stated that work stress could mediate work condition influence toward loan collection performance. It means that good work environment condition causing decreasing work stress and impact on increasing loan collection performance. Good environment condition could be achieved from work facilities and infrastructures that meet standard from air circulation, exposure level and without exception colleague relationship. Facilities and infrastructures fulfillment could provide impact on decreasing employee work stress level. Decreased work stress could simplify employee to complete work and shall provide good result, that it could increase loan collection performance. This research result was in line with research conducted by Taiwo (2010) that provided empirical evidence that conducive and better work environment are factors causing employee productivity enhancement.

\section{CONCLUSION}

This research examined work stress mediating effect on workload, Work condition and loan collection performance. The following are conclusion of this research: (1) research result showed that stress could mediate workload influence toward loan collection performance. It suggests that high workload causing increased work stress and eventually impact on loan collection performance decrease. (2) Research also showed that work stress could mediate Work condition influence toward loan collection performance. It suggests that good Work condition causing reduced work stress and impact on increasing loan collection performance.

\section{REFERENCES}

1. Adityawarman, Y., (2016). Pengaruh Beban Kerja terhadap Kinerja Karyawan PT. Bank Rakyat Indonesia Tbk Cabang Krekot. Jurnal Manajemen and Organisasi 6(1): 34-44.

2. Ahmed, A. (2013). Effects of Job Stress on Employees Job Performance A Study on Banking Sector of Pakistan. IOSR Journal of Business and Management. 61-68.

3. Ali (2013). Working Conditions and Employees Productivity in Manufacturing Companies in Sub-Saharan African Context. Educational Research International 2(2): 67-78.

4. Andrew, A. and R. Kishokumar (2014). Influence of Working Environment and Workload on Occupational Stress Among Staff in The Financial Services Industry. International Journal on Global Business Management \& Research 3(1): 70.

5. Arianto, D. A. N. (2013). Pengaruh Kedisiplinan, Lingkungan Kerja and Budaya Kerja Terhadap Kinerja Tenaga Pengajar. Jurnal Economia 9(2): 191-200. 
6. Astianto, A. (2015). Pengaruh Stres Kerja and Beban Kerja Terhadap Kinerja Karyawan PDAM Surabaya. Jurnal IImu \& Riset Manajemen 3(7).

7. Baron, R. M. and D. A. Kenny (1986). The Moderator-Mediator Variable Distinction in Social Psychological Research: Conceptual, Strategic, and Statistical Considerations. Journal Of Personality and Social Psychology 51(6): 1173.

8. Carayon, P. and A. P. Gürses (2005). A Human Factors Engineering Conceptual Framework of Nursing Workload And Patient Safety in Intensive Care Units. Intensive and Critical Care Nursing 21(5): 284-301.

9. Doelhadi, A. S. S., M. (1995). Keterkaitan Pengalaman Coping dengan Dampak Negatif Stres. Jurnal Anima 10(38): 258-282.

10. Ghozali, I. (2013). Aplikasi Analisis Multivariat dengan Program IBM SPSS 21. Semarang, Universitas Diponegoro.

11. Giorgi, G., (2017). Work-Related Stress in the Banking Sector: A Review of Incidence, Correlated Factors, and Major Consequences. Frontiers in psychology 8: 2166.

12. Griffin, M. L., N. L. Hogan, et al. (2010). Job Involvement, Job Stress, Job Satisfaction, and Organizational Commitment and The Burnout of Correctional Staff." Criminal Justice and behavior 37(2): 239-255.

13. Hart, S. G. (1988). Development of NASA-TLX (Task Load Index): Results of empirical and theoretical research. Advances in psychology, Elsevier. 52: 139-183.

14. Kahya, E. (2007). The Effects of Job Characteristics and Working Conditions on Job Performance. International Journal of Industrial Ergonomics 37(6): 515-523.

15. Khan, N. S., A. Riaz, et al. (2011). The impact of work content, working conditions, career growth on employee motivation. Interdisciplinary Journal of Contemporary Research in Business 3(3): 1428-1434.

16. Lovibond, P. F. and S. H. Lovibond (1995). The Structure of Negative Emotional States: Comparison of the Depression Anxiety Stress Scales (DASS) With the Beck Depression And Anxiety Inventories. Behaviour Research and Therapy 33(3): 335-343.

17. Mahoney, T. A. (1963). Development of managerial performance: A research approach, South-western Publishing Company.

18. Mangkunegara, A. A. P. (2010). Perilaku and Budaya Organisasi. PT. Refika Aditama.

19. Mangkunegara, A. A. P. (2014). Evaluasi Kinerja SDM. Bandung, PT. Refika Aditama.

20. Murali, S., A. Basit, et al. (2017). Impact of Job Stress on Employee Performance. International Journal of Accounting \& Business Management 5(2).

21. Putra, F. R. (2013). Pengaruh Lingkungan Kerja Terhadap Kinerja (Studi Pada Karyawan PT. Naraya Telematika Malang). Jurnal Administrasi Bisnis 6(1).

22. Robbins, S. (2017). Perilaku Organisasi. Jakarta, Salemba Empat.

23. Saefullah, E. and A. N. Amalia (2017). Pengaruh Beban Kerja and Stres Kerja Terhadap Produktivitas Kerja Karyawan. Jurnal Akademika 15(2): 117-121.

24. Sasono, E. (2004). Mengelola Stres kerja. Semarang, Universitas Pandanaran.

25. Sedarmayanti (2011). Tata Kerja and Produktifitas Kerja. Bandung, CV. Mandar Maju.

26. Shah, S. S. H., A. Jaffari, et al. (2011). Workload and Performance of Employees. Interdisciplinary Journal of Contemporary Research in Business 3(5): 256-267.

27. Sholihin, M., Dwi Ratmono (2013). Analisis SEM-PLS dengan WarpPLS 3.0 untuk Hubungan Nonlinier dalam Penelitian Sosial and Bisnis. Yogyakarta, CV. Andi Offset.

28. Solimun, A. A. R. F., Nurjannah (2017). Metode Statistika Multivariat Permodelan Persamaan Struktural (SEM) Pendekatan WarpPLS. Malang, UB Press.

29. Sugiyono. (2017). Metode Penelitian Bisnis. Bandung, Alfabeta.

30. Sugiyono. (2017). Statistika Untuk Penelitian. Bandung, Alfabeta.

31. Sutanto, E. M. (2015). Hubungan lingkungan kerja, disiplin kerja, and kinerja karyawan. Jurnal manajemen and kewirausahaan 17(2): 135-144.

32. Taiwo, A. S. (2010). The influence of work environment on workers' productivity: A case of selected oil and gas industry in Lagos, Nigeria. African Journal of Business Management 4(3): 299-307.

33. Wolfe, D. M. and J. D. Snoek (1962). A Study of Tensions and Adjustment under Role Conflict. Journal of Social Issues 18(3): 102-121 